\title{
ОЛОН ФУНКЦИОНАЛЬТ БАЙГАЛИЙН ПОЛИМЕРТ СУУРИЛАН МӨНГӨ АГУУЛАН ЭРЛИЙЗЖСЭН НАНОКОМПОЗИТ НИЙЛЭГЖҮҮЛЭХ
}

\author{
Г. Долмаа', Г.П. Александрова² У. Энхбадрал", \\ Л.А. Гришенко ${ }^{2}$ Б.Г. Сухов ${ }^{2}$, Д. Рэгдэл ${ }^{1}$, Б.А. Трофимов ${ }^{2}$ \\ ${ }^{1}$ ШУА-ийн Хими, хими технологийн хүрээлэн, Dolmaa g@yahoo.com \\ 2 Оросын ШУА-ийн СС-ын Иркутскийн Химийн хүрээлэн
}

Хураангуй

Эрлийзжсэн нанокомпозитыг нийлэгжүүлэхдээ усан уусмалаас органик биш материалын цөм онцгой адсорбцлох чанар бүхий олон функциональт биогенны полимерийн гадаргууд агрегацлагдах шинэ тохиромжтой алхамыг ашигласан. Биогенны тогтворжуулагч болох гумины бодисыг (ГБ) эх орны түүхий эд пелоидоос ялган авч бүтэц байгуулалтыг баталсны дараа нано композитын нийлэгжүүлэлтэд хэрэглэв. Тогтворжуулагчийн гадаргууд мөнгөний органик бус цөм агрегацлагдах чанар нь бидний гарган авсан эрлийзжсэн органик бус-органик нано бүтэц өөрөө үүсэх нөхцөлийг хангаж байгаа юм. Гарган авсан нанокомпозитын шинж чанарыг ИК-, УФ-, Рентгенфазын задлан шинжилгээний дүнд тогтоолоо.

\section{Оршил}

Эмчилгээний шаварт агуулагддаг амьтан ургамлын үлдэгдэлийн лигнин идээлэгч бодисууд, ароматик амин болон амин хүчлүүд, эслэг, гемицеллюлоз, органик хүчлүүд, олигосахарид зэрэг нэгдлүүд микроорганизмын үйл ажиллагааны нөлөөгөөр ГБ болон хувирдаг. Гумины бодис нь байгалийн биологийн идэвхит олон функциональт полимер нэгдэл бөгөөд энэ үндсэн дээр шинэ төрлийн эмийн бодисыг бий болгох боломжийг орчин үеийн нано технолог олгож байна. Эмчилгээний шаварт агуулагддаг ГБ нь нүүрс, торф, хөрсний ГБ-ыг бодвол молекул жин харьцангуй багатай, функциональ бүлгийн агуулга өндөртэй байдаг [1, 2].

ГБ-ын молекул дахь ароматик цөм, функциональ бүлгүүд нь организмын эсийн хана , арьсны хүлээн авууруудтай харилцан үйлчлэлцэж, улмаар эд эсд нэвчин орох замаар эмчилгээний үйлчлэл үзүүлдэг[3]. ГБ-ын үндсэн дээр шинэ төрлийн эмийн бодисыг бий болгох замаар түүний биологийн идэвхийг нэмэгдүүлэх, үйлчлэлийн хугацааг уртасгах, хоруу чанар ба хажуугийн нөлөөлөлийг багасгах, үйлчлэлийн сонгомол болон уусах чанарыг нэмэгдүүлэх зэрэг асуудлыг шийдвэрлэх боломжтой гэж үздэг. 
Монгол орны нууруудын эмчилгээний шаврын органик хэсгийн ихэнх хувийг эзэлдэг ГБ нь шаврын найрлага дах нарийн органоминеральны комплекстой холбогдох ба ингэснээр нанотогтворжуулагч шинж чанартай байж болох юм гэсэн таамаглалыг дэвшүүлж энэхүү судалгааг явууллаа.

Судалгааны зорилго нь:

- Эмчилгээний шаварт агуулагдаж байгаа ГБ-ын шинж чанарыг тогтоох,

- ГБ ба нано хэмжээст биоидэвхит металлын цөмийн харилцан үйлчлэлээр шинэ төрлийн нанокомпозитыг гарган авах аргачлалыг боловсруулах,

- Эмчилгээний шавраас ялгасан ГБ дээр суурилсан мөнгө агуулсан шинэ төрлийн нанокомпозитыг нийлэгжүүлэн, найрлага, шинж чанарыг тогтооход тус тус оршино.

Түлхүур үг: Нанокомпозит, органоминералын комплекс, гумины бодис, пелоид

\section{Судалгааны материал, арга зүй}

Пелоидоос ГБ-ыг ялгасан аргачилал: Гурван нуурын дунд нуурын кальцгүйжүүлж, битумгүйжүүлсэн эмчилгээний шавраас ГБ-ыг 0,2N; 0,3N гидроксид натрийн уусмалаар 1 цагийн турш хандлан дараа нь 0,1N давсны хүчлийн уусмалаар pH-2-3 болтол хүчиллэгжүүлэн тундасжуулав [4]. Үүссэн тунадасыг хатааж нанокомпозитын нийлэгжүүлэлтэд зориулж гадаргууг ихэсгэх зорилгоор механоидэвхжүүлэлтэд 5 ба 10 мин хугацаатайгаар оруулсан болно.

ГБ нь ДМСО ба спирт зэрэг органик уусгагчид уусах чадвартай болохыг судалгааны явцад илрүүллээ. Харин шүлтлэг орчинд усанд уусна.

ГБ-Ag нанокомпозитын нийлэгжүүлэлтийн аргачилал: Бид эхний туршилтуудад полисахаридын үндсэн нанокомпозит гаргах аргачиллыг [5] ашиглаж улмаар цааш модификацид оруулах замаар ГБ-Аg нанокомпозитыг нийлэгжүүлэв. Үүнд: ГБ 0,4 г-ыг (№ 14) жинлэж аваад 6 мл 1,0 N NaOHийн уусмал нэмж 15 минут зөөлөн халааж бүрэн уустал нь хутгана. Хутгах явцдаа 360 мг $\mathrm{AgNO}_{3}$ агуулсан 5 мл мөнгөний уусмалыг нэмнэ. Азот хүчлийн мөнгөний уусмалыг нэмэх үед тунадас үүсвэл $1 \mathrm{~N} \mathrm{NaOH-ыг} \mathrm{бага} \mathrm{багаар}$ нэмж үүссэн тунадасыг арилган 15 минут усан халаагуур дээр халаана. Уусмалаа халуунаар нь цаасан шүүлтүүрээр шүүнэ. Шүүгдэс рүү 4 дахин их эзэлхүүнтэй этанол нэмж, үүссэн тунадасыг центрфугдэж ялгав. Тунадасыг вакуум эксикаторт хатаана.

Пелоидоос ялгасан ГБболон гарган авсан шинэ төрлийн нанокомпозитын найрлага, бүтэц байгуулалтын судалгааг орчин үеийн физик химийн аргууд тухайлбал элементийн бичил шинжилгээ, ИК, УФ, Рентген фазын задлан шинжилгээний тусламжаар явуулсан. 


\section{Судалгааны үр дүн}

\section{Эмчилгээний шаврын биоминеральны комплекс - Гумины бодисын найрлага ба бүтцийн судалгаа}

Ялган авсан ГБ-ын үнслэг бага (0,0-2,7\%). H/C харьцаа 0,11-0,13 болон азотын агуулга (5\%)-аараа байгалийн бусад объектоос ялгасан ГБ-той ойролцоо байна[2]. ГБ дахь хүчилтөрөгчийн агуулга 30-40\% байгаа нь азотын агуулгаас 6-8 дахин өндөр үзүүлэлт юм. Иймд ГБ-ын биогенны металлтай урвалд орох чадвар нь хүчилтөрөгч агуулсан фрункциональ бүлэг ялангуяа фенолын гидроксилтэй холбоотой.

$1-\mathrm{p} \mathrm{хүснэгт}$

Гурван нуурын эмчилгээний шавраас ялгасан ГБ-ын элементийн задлан шинжилгээний дүн

\begin{tabular}{|c|c|c|c|c|c|c|c|c|}
\hline$\frac{\sum^{1}}{\overbrace{}^{2}}$ & $\begin{array}{c}\text { NaОН-ийн } \\
\text { Концентрац }\end{array}$ & $\begin{array}{c}\text { Тээрэмдсэн } \\
\text { хугаиаа } \\
\text { (мин) }\end{array}$ & $C, \%$ & $H, \%$ & $N, \%$ & $\mathrm{Cl}$ & $\begin{array}{c}\text { Үнслэг, } \\
\%\end{array}$ & $\begin{array}{c}H / C \\
\text { харьияаa }\end{array}$ \\
\hline$I$ & $0.3 N$ & 10 & 47,77 & 6,41 & 5.19 & - & 2.35 & 0,13 \\
\hline$I I$ & $0.2 \mathrm{~N}$ & 10 & 49,83 & 5,47 & 5.28 & - & 2.70 & 0,11 \\
\hline III & $0.2 \mathrm{~N}$ & 5 & 49.93 & 5.47 & 5.39 & - & - & 0,11 \\
\hline$I Y$ & $0.2 \mathrm{~N}$ & 0 & 48.85 & 5.44 & 5.02 & 1.27 & 0.0 & 0,11 \\
\hline
\end{tabular}

ГБ нь бүтэц байгууламжийнхаа хувьд азот агуулсан фррагмент бүхий ароматик полиоксикарбон хүчлийн хатуу дараалалгүй полимер юм. Полимерийн гол араг яс нь алкил болон функциональ бүлгээр халагдсан ароматик цагираг түүнд полисахарид, полипептидын фррагментууд холбогдсон байдаг. 


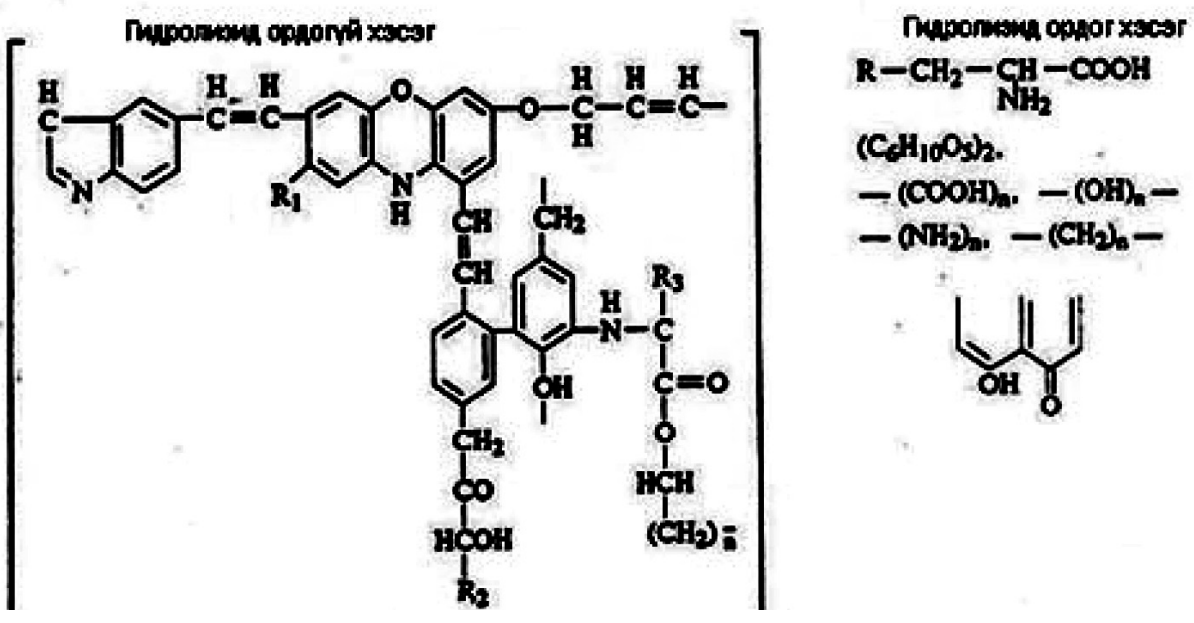

1-р зураг. Гумины хүчлийн фрагментын нийтлэг бүтэц (Д.С.Орлов 1994)

Бидний ялгаж авсан ГБ-ын ИК-спектрт $3424 \mathrm{~cm}^{-1}-$ гидроксилийн бүлгийн, $2922 \mathrm{~cm}^{-1}$-д метилен бүлгийн урт хэлхээний, $2853 \mathrm{~cm}^{-1}-$ д төгсгөлийн метилийн бүлгийн, 1623-1591, $1383 \mathrm{~cm}^{-1}$-д бензоидны бүтцийн, $1227 \mathrm{~cm}^{-1}$-д эфирийн С-О бүлгийн, 1075-1037 см-1-д нүүрсусны СО бүлгийн шингээлтийн зурвасууд тус тус илэрч байна. Гарган авч боловсруулсан аргаасаа хамаарч шингээлтийн эрчим бага зэргийн ялгаатай байлаа. 


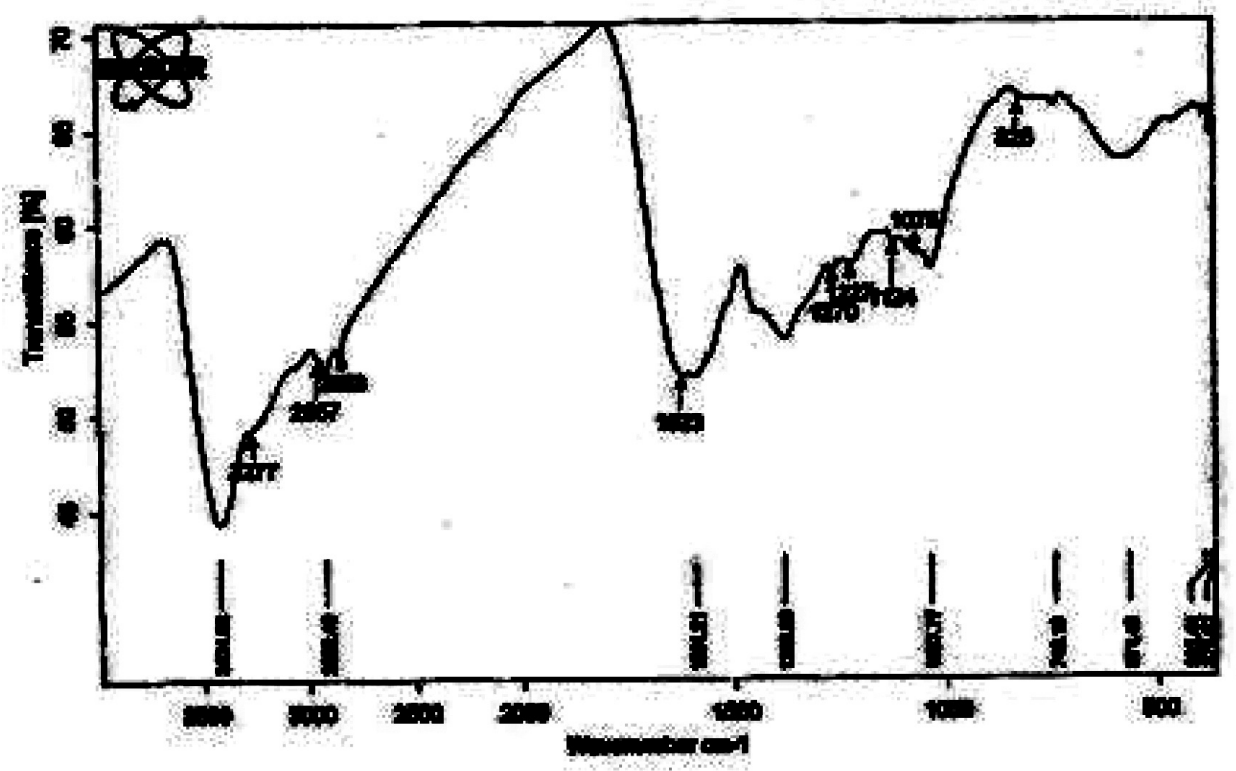

2- зураг. Гумины бодисын ИК-спектр (KBr).

Функциональ бүлгийн агуулгад тоон үнэлэлт өгөхийн тулд хүчилтөрөгч агуулсан шингээлтийн зурвасын эрчмийг (ШЗЭ) харгалзах ароматик полисопряженны систем (1623 см-1 ), алифратик халагч $\left(2957\right.$ см$\left.^{-1}\right)$-ийн оптик нягтад харьцуулалт хийв.

ГБ-ын бүтцийн параметрийн тооцоо (2-р хүснэгт)-оос түүнийг гарган авсан аргаас хамаарахгүйгээр фрункциональ бүлгийн найрлага тогтмол, нэг төрлийн болох нь тогтоогдож байна.

Эмчилгээний шаврын ГБ дахь хүчилтөрөгч агуулсан бүлгийн үндсэн хэлбэр нь феенолын болон нүүрсусны гидроксил (ОН), нүүрс ус болон эфирийн карбонил (С-О) бүлгүүд юм. Гидроксил ба карбонил бүлгийн ароматик фррагментад харьцуулсан ШЗЭ-ийн харьцаа нь $3424 \mathrm{~cm}^{-1}$ мужид ароматик бүтэц давамгайлж байгааг, $1227 \mathrm{~cm}^{-1}$-т эфирийн СО бүлэг ароматик фрагментийг давамгайлж байгааг тус тус үзүүллээ. Түүнчлэн эфирийн бүлгийн тоо хэмжээ алифатик хэсгийн С-H холбооны тоо хэмжээнээс их байна.

АлкилхалагчийнШЗЭ-ийгароматикфрагментынхадхарьцуулсанхарьцаа бараг тогтмол байгаа юм. ГБ дахь гидроксил бүлгийн $\left(\mathrm{D}_{3424} / \mathrm{D}_{1623}\right)$ харьцангуй тоо хэмжээ их биш ба алкил бүлгийн хувьд авч үзэхэд энэ хэмжигдэхүүн бага байна. Композитуудын спектрийн коэфффициентоор илэрхийлэгдсэн шаврын ГБ-ын бүтэц дэх гидрофил, гидрофоб бүрдүүлэгчийн харьцаа $\left(\mathrm{OH}_{3424}{ }^{\prime}\right.$ Салк ${ }_{2922}$ ) туршилтын бүтээгдэхүүн тус бүрийн хооронд мэдэгдэхүйц ялгаa 
байгааг харууллаа.

2-р хүснэгт

ГБ-ын ИК-спектрийн тодохой долгионы уртууд дах ШЗЭ-ийн харьцаа

\begin{tabular}{|c|c|c|c|c|c|c|}
\hline ШЗЭ харьияаа & \multicolumn{3}{|c|}{ 0,2 н $\mathrm{NaOH}$ (II дээж) } & \multicolumn{3}{|c|}{0,3 н $\mathrm{NaOH}$ (I дээж) } \\
\hline $\mathrm{OH}_{3424} / \mathrm{C}=\mathrm{C}_{1623}$ & 44 & 52 & 0,84 & 25 & 34 & 0,73 \\
\hline Салк $_{2922} / \mathrm{C}=\mathrm{C}_{1623}$ & 52 & 52 & 1,00 & 36 & 34 & 1,06 \\
\hline $\mathrm{CO}_{1227} / \mathrm{C}=\mathrm{C}_{1623}$ & 57 & 52 & 1,10 & 43 & 34 & 1,26 \\
\hline $\mathrm{OH}_{3424} /$ Салк ${ }_{2922}$ & 44 & 52 & 0,84 & 25 & 36 & 0,69 \\
\hline $\mathrm{CO}_{1227} /$ Салк 2922 & 57 & 52 & 1,10 & 43 & 36 & 1,19 \\
\hline
\end{tabular}

Судалгаанд авсан ГБ-ын УФ-спектр нь байгалийн янз бүрийн объектоос ялгасан ГБ-той адил байна [6]. Үүнд: Спектрийн богино долгионы хэсэгт хамгийн их оптик нягттай шингээлт 285 нм долгионы уртад максимумтайгаар ажиглагдсан ба энэ нь феенолын гидроксилийн бүлэгт харгалзаж байгаа юм. Оптик нягт цааш спектрийн урт долгионы хэсэг хүртэл буурч байна (3-p зураг).

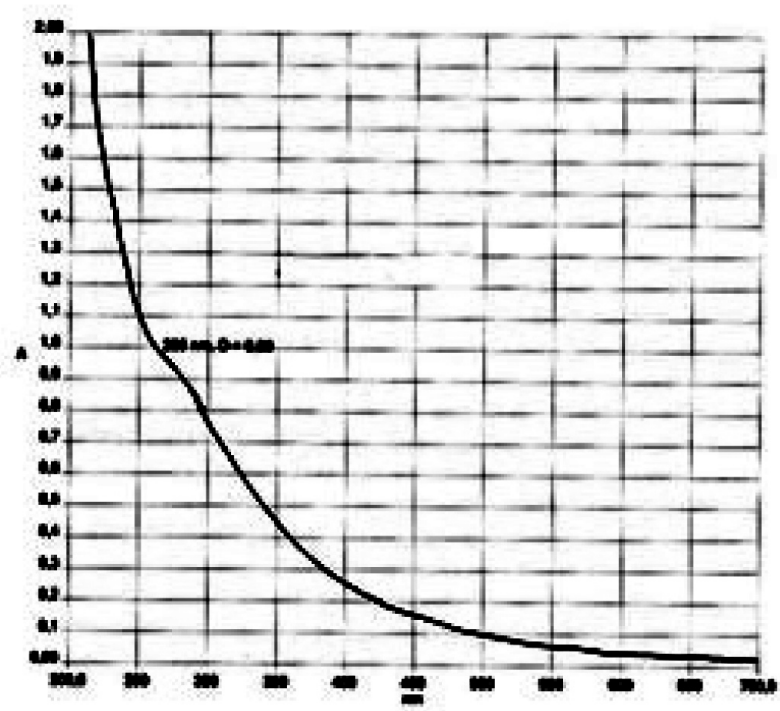

3-р зураг. Гумины бодисын электронны спектр (натри шүлтийн уусмалд)

Эмчилгээний шаврын органик бодист зонхилон агуулагддаг

биополимер ГБ-ийн үндсэн дээр эрлийзжсэн органик бус-органик

нанобиокомпозитын нийлэгжүүлэлтийн арга боловсруулах 
Металлополимер нанокомпозитууд нь (гибрид) эрлийзжэн бүрэлдэн тогтсон материалуудын онцгой бүлэг нэгдэл юм. Тэдгээрт нано тогтворуужлагч полимер матрицууд нь бүтэц бүрэлдэн тогтоход гол үүрэгтэй. Нано хэсэг хэлбэржих зүй тогтлын судалгаа, тэдгээрийн хэмжээсийн үр нөлөөг нөхцөлдүүлсэн оптик чанар ба бүтцийн задлан шинжилгээ нь нано хэмжээст бодисын шинж чанарын талаар зарчмын мэдээлэл авах эх үүсвэр болж байна.

Ирээдүйтэй шинэ төрлийн эмийн бодисыг бий болгохын тулд Монгол орны Хэнтий аймгийн нутагт орших Гурван нуурын дунд нуурын эмчилгээний шавраас ялгасан ГБ-ын мөнгө агуулсан нанокомпозитын нийлэгжүүлэлтийг ерөнхий аргачилалд үндэслэн боловсруулав [5]. Харин гибридны нанокомпозитыг бий болгохын тулд түүний найрлаганд орж байгаа органик бус материалын цөм усан уусмалаас матрицын гадаргуу руу агрегацлагдах болон биогенны полимерийн адсорбцлох онцлог зэрэг дээр үндэслэсэн шинэ алхамыг ашиглалаа. Энэ нь бидний гарган авсан органик бус-органик нано бүтэц өөрөө зохион байгуулагдан бүрэлдэн бий болох нөхцлийг бүрдүүлсэн хэрэг юм.

\section{Өөрөө бүрэлдэн тогтох зарчим}

Энэ ажлын эхний үе шат нь ГБ-ын үндсэн дээр металл агуулсан олон фуннцциональт эрлийзжсэн органик бус-органик нанокомпозитыг бий болгох зарчмыг боловсруулахад чиглэгдэж байлаа. Үүний тулд байгалийн гаралтай усанд уусдаг нано тогтворжуулагч матрицыг ашиглан нанокомпозитыг нийлэгжүүлэх аргыг боловсруулсан. Хэмжээс болон дисперсжилт нь зохицуулагдахуйц нано хэмжээст олон функциональт органик бус-органик композитыг гарган авах нөхцөлийг тогтоох замаар ерөнхий стратеги боловсрогдож эхэллээ. Бид нано тогтворжуулагч матрицаар ГБ-ыг, нано хэмжээст цөмөөр мөнгийг тус тус ашиглав. Аg-ГБ хэлбэрийн нанокомпозитыг гарган авахын тулд ГБ-ыг шүлтлэг усан уусмалын орчинд мөнгөний давстай харилцан үйлчлүүлэх урвалыг ашигласан болно. Урвалын бүтээгдэхүүн дэх мөнгөний агуулгыг атом шингээлтийн спектрометрийн аргаар тодорхойлж 3-р хүснэгтэнд хавсаргав.

ГБ-ын матриц дах мөнгөний нанокомпозитын найрлага

3-р хүснэгт.

\begin{tabular}{|c|c|c|c|}
\hline Туршилтын дугаар & $\begin{array}{c}\text { Туршилтанд авсан } \\
\text { Ag, мг }\end{array}$ & $\begin{array}{c}A g, \% \\
\text { (нанокопозитод) }\end{array}$ & Хуурай үлдэгдэл, \% \\
\hline ГВ- $A g$ № 3 & 36 & 9,5 & $47,5 \%(0.095$ гр) \\
\hline ГВ- $A g$ № 4 & 72 & 15,8 & $31,6 \%(0.063$ гp) \\
\hline ГВ- $A g$ № 5 & 18 & 5,5 & $65,9 \%(0.132$ гp) \\
\hline
\end{tabular}




\begin{tabular}{|c|c|c|c|}
\hline ГВ- $A g$ № 6 & 72 & 15,5 & $29,5 \%(0.059$ гр) \\
\hline ГВ- $A g$ № 7 & 54 & 12,0 & $95,1 \%(0.190$ гр) \\
\hline ГВ- $A g$ № 8 & 180 & 24,8 & $95,0 \%(0.190<p)$ \\
\hline ГВ- Ag № 13 & 360 & - & - \\
\hline ГВ- $A g$ № 14 & 360 & - & - \\
\hline ГВ- Ag № 10 & 1,36 адсорби & 0,36 & $45 \%(0.090)$ \\
\hline
\end{tabular}

Гарган авсан органик бус-органик нанокомпозитын ИК-спектрийн шингээлтийн зурвасын байрлал ба эрчим нь ГБ-ынхоос төдийлөн ялгагдахгүй байна. Энэ нь ГБ-ын химийн бүтэц байгуулалт хадгалагдан үлдсэнийг гэрчилж байгаа юм. Ag-ГБ нанокомпозитын гарц нийлэгжүүлэлтийн нөхцөлөөс хамаарч 47-95\%, мөнгөний хэмжээ 5,5-24,8\% хооронд хэлбэлзэж байна.

Бидний гарган авсан ГБ-Ag нанокомпозитууд нь үзэгдэх гэрлийн долгионы мужид 424 нм-т максимум бүхий шингээлт өгсөн нь тэдгээрт тэг валенттай мөнгө агуулагдаж байгааг гэрчилнэ. Энэ нь Оросын судлаачдын нано хэмжээст мөнгө бүхий нэгдлийн талаар хийсэн судалгааны ажлын дүнтэй тохирч байна[7, 8]. Металл композитын спектрт илэрсэн дээрх максимум бүхий шингээлт нь металлын өдөөгдсөн электрон дамжуулалт (плазменны резонанс)-аар нөхцөлдөн илэрч байгаа юм. Иймээс усанд уусдаг өндөр үр ашигтай шугаман бус оптик материалыг бий болгох нь чухал байдаг [9]. Мөнгөний ангижрах процесс ГБ-ын найрлаганд байгаа френолын гидроксилийн исэлдэх чадварын дүнд явагдаж байгаа нь тодорхой. Ийм байдлаар гарган авсан нанокомпозитууд уусмал байдалдаа удаан хугацаанд цогц байдалтайгаар тогтвортой орших, мөн хуурайгаар ялган аваад буцааж уусгах үед энэ чанараа хадгалах чадвартай байдаг нь практик хэрэглээнд маш чухал юм. 


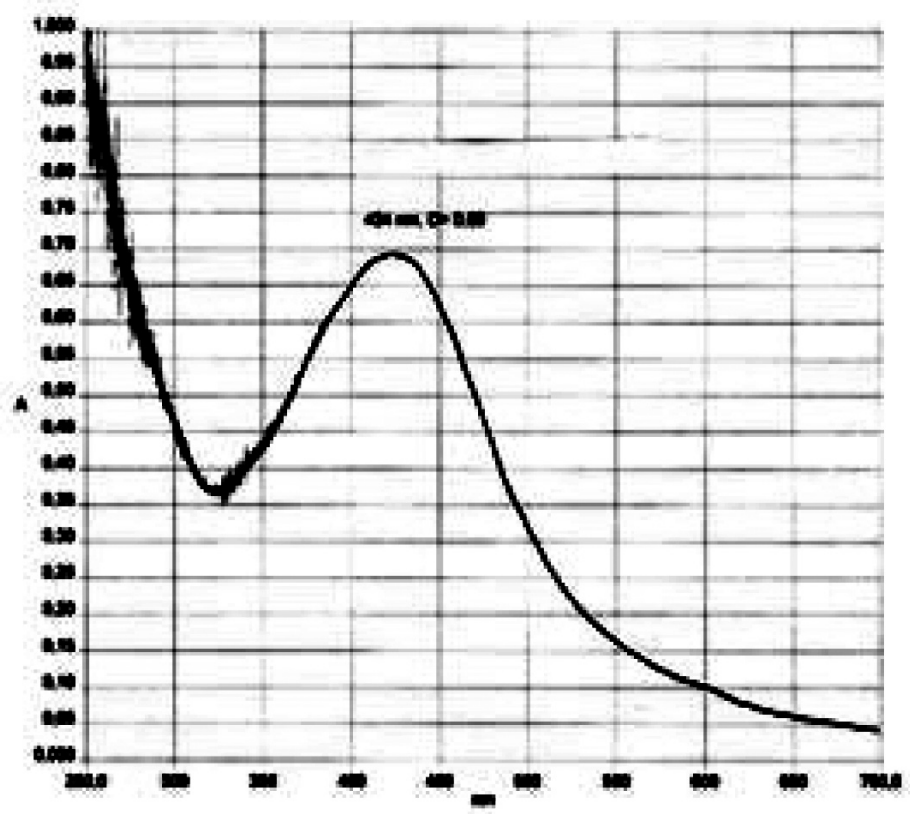

4-р зураг. ГБ-ын матриц дахь мөнгөний нанокомпозитын электроны шингээлтийн спектр

Гарган авсан металлогумины композитын органик бус компонентын бүтэц байгуулалтыг таньж тодорхойлох ажлыг рентгендифракцын задлан шинжилгээ (дифрактометр D8 ADVANCE CuKa),-ний аргаaр гүуцэтгэхэд, гарган авсан бүтээгдэхүүн бүр бүгд нэг адил нано композитод хамаарагдаж байна. Эдгээр нанокомпозитууд нь аморфр-талст хоёр фразт бүтэцтэй байгаа юм. Дифрактограмм (5-р зураг) органик бус бүрэлдэхүүнд нь тэг валенттай мөнгөний бүтэц байгааг баталж байна. Ионы хэлбэрт байгаа мөнгөний анхны прекурсорын дифрракцын шугам илрээгүй байгаа нь ангижрах процесс бүрэн явагдсаныг нотолж байгаа юм. Композитуудын дифракцын шугамын эрчмийн тархалт ба хавтгай хоорондын зай нь мөнгөний стандарт шугамуудынхтай тохирч байна. Гарган авсан бүтээгдэхүүнд тэг валенттай металл мөнгө байгааг электроны спектр болон рентген дифракцийн задлан шинжилгээ давхар баталж байгаа юм. 


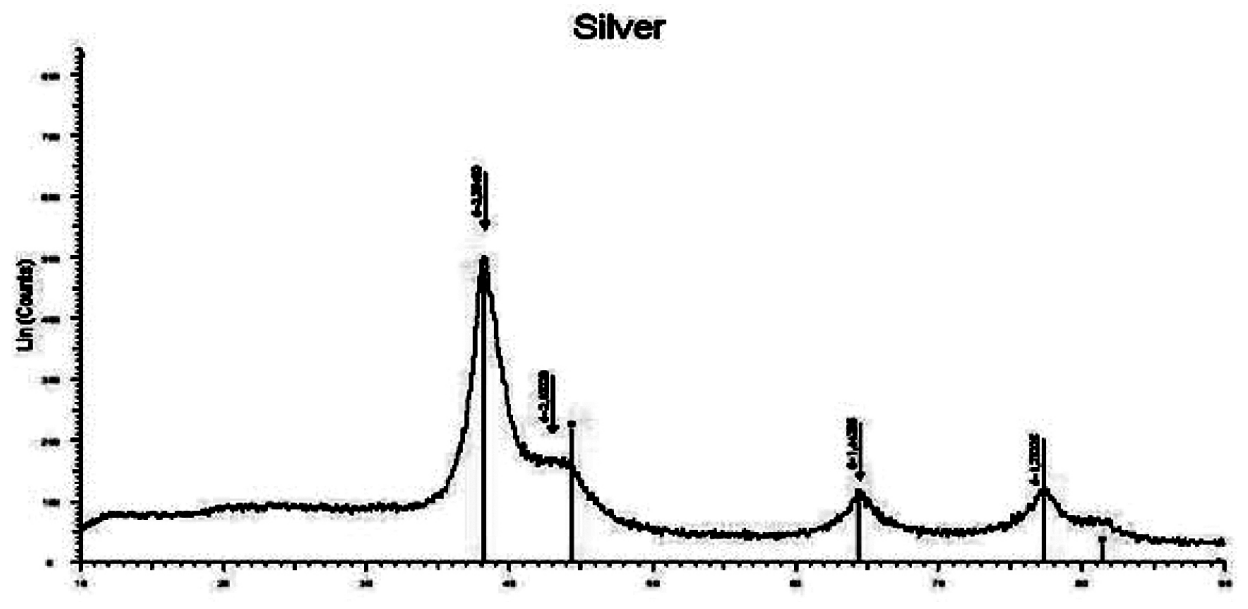

5-р зураг. Гурван нуурын шаврын органоминеральны комплексоос ялгасан ГБ-оор тогтворжуулагдсан тэг-валенттай мөнгөний нанокомпозитын дифрактограмм

Мөнгөний нано хэсгийн когерент сарнилын мужийн дундаж хэмжээ ба эгэл үүрийн параметрүүдийн утгыг 111 шугамаар тооцоход, эгэл үүрийн а параметрүүд 4,059(1)-4,077(1)А॰ хязгаарт, мөнгөний нано хэсгийн когерент сарнилын мужийн дундаж размер L бүх туршилтын бүтээгдэхүүнд 8,6 нм байгаа нь нано хэмжээст цөмийн металл фазын маш чухал шинж чанарыг үзүүлж байгаа юм (4-р хүснэгт).

4-р хүснэгт

ГБ дээр суурилсан нанокомпозит дах мөнгөний нанохэсгийн когерент сарнилын мужийн дундаж размер (L) ба эгэл үүрийн $(\alpha)$ параметрүүд

\begin{tabular}{|l|l|l|}
\hline Туриилтын дугаар & $\boldsymbol{a}($ E) & $L(E)$ \\
\hline 8 & $4.059(1)$ & $86.0(5)$ \\
\hline 13 & $4.059(4)$ & $86.2(3)$ \\
\hline 14 & $4.068(1)$ & $86.6(1)$ \\
\hline 16 & $4.077(1)$ & $86.0(5)$ \\
\hline
\end{tabular}

Коллоид системийн агрегат бат бэх чанар жижиг хэсгүүдийн сольватац ба цахилгаан статик хүчний түлхэлцлэл зэрэг хэд хэдэн хүчин зүйлээр тодорхойлогддог. Усан уусмал дахь ГБ-ын полианионууд юуны өмнө мөнгөний нано хэсгийн илүүдэл эерэг цэнэгтэй цахилгаан статик харилцан үйлчлэлцэлд орох нь тодорхой. Тийм харилцан үйлчлэл нь суспензийг коагуляцд оруулах талтай. Гэвч эсрэгээрээ бидний судалгаанд авсан ГБ ба 
нано хэсгийн өгөгдсөн харьцааны тохиолдолд коллоид систем хангалттай тогтвортой байна. Энэ нь ГБ-ын фрункциональ бүлэг нано хэсгийн гадаргуу дээрх бүх боломжит координацын байрлалыг эзэлж байгааг, өөрөөр хэлбэл усны молекулын хувьд харьцангуй хүчтэй координацлагдсан тэг-валенттай мөнгө гидроксил бүлгийг агуулсан ГБ-ын глобуляр бүтцэд шингэн, улмаар илүү жижиг нано хэсгүүд нь түүний полианионоор хучигдан буйг харуулж байна. Нано хэсгийн гадаргуутай холбогдсон ГБ, гарган авсан нанокомпозитын гидрофиль чанарыг нэмэгдүүлж улмаар усан фазд улам тогтвортой болгож байна.

Ингэж ГБ-ыг матриц болгон хэрэглэх замаар усан уусмалд тогтвортой тэг-валенттай мөнгөний нано хэсгийг агуулсан нанокомпозитыг гарган авах боломж олдож байна. Эндээс ГБ-ын салбарласан полифункциональт бүтцэд нано хэсгийг нэвтрүүлсэнээр тогтворжилт хангагдаж байгаа нь тодорхой байна.

Нано хэсгийн шинэ төрлийн органик тогтворжуулагч болгон ГБ-ыг хэрэглэсэнээр хэд хэдэн асуудлыг шийдвэрлэх боломж олдож байна. Үүнд:

- ББ нь анхныхаа глобулын размерт харгалзах хэмжээ бүхий ассоциат хувиарлагдан байрших нэг төдийгүй, хэд хэдэн нанохэсгийг нэвтрүүлж чадах салбарласан молекул бүтэцтэй учир усан уусмал ба нано хэсгүүдийг тогтворжуулах чадвартай байна.

- Мөн түүнчлэн ГБ-ын глобулд нэвтрэх нано хэсэг болон ГБ-ын харьцааг өөрчилсөнөөр үүсэх нанокомпозитуудын биологийн идэвхит чанарыг хянах боломжтой болно.

- Нано мөнгө агуулсан шинэ төрлийн нанокомпозитыг бий болгоход ГБыг ашиглах нь элбэг олдоцтой хямд төсөр тул ирээдүйд эх орныхоо түүхий эдийг нанотехнологит цоо шинээр ашиглах өргөн боломж бидний өмнө нээгдэж байна.

\section{Дүгнэлт}

1. Эмчилгээний шавраас органоминералны комплекс-олон функционалт биополимерыг ялган бүтэц байгууламж шинж чанарыг нь тогтоон шинээр нано тогтворжуулагч болгон ашиглах нөхцөлийг бүрдүүлэв.

2. Шинэ төрлийн органик нано тогтворжуулагчийг ашиглан органик бус-органик эрлийзжсэн нанокомпозитыг нийлэгжүүлэх арга боловсруулж, гарган авсан нанокомпозитын найрлага шинж чанарыг элементийн бичил шинжилгээ, атом шингээлтийн спектрометр ИК, УФ, рентгенфразын задлан шинжилгээгээр тогтоов. 


\section{Ашигласан хэвлэл}

1. Шинкаренко А.Л., Миленина Н.Г., Органические вещества лечебных грязей и их роль в механизме лечебного действия на организм // Грязевые препараты. Томск.: 1981 с. 30 - 33.

2. Косьянова ЗФ., Орлов Д.С., Аммосова Я.М. Гуминовые кислоты пелоидов //Гуминовые вещества в биосфере. М.: Изд-во “Наука”. 1993. С. $74-79$

3. Левицкий Е.Ф., Кузьменко Д.И., Лаптев Б.И., Современное представление о механизмах физиологического и лечебного действия лечебных грязей и питьевых минеральных вод //Комплексное применение природных лечебных фракторов и поля постоянных магнитов в эксперименте и клинике. Изд-во Томского Ун-та с. 7-12

4. Долмаа. Г., Цэрэнпил. Ш., Угтахбаяр Ө. Эмчилгээний шавраас гумины бодисыг ялгах арга Монгол улс патент №2445, Оюуны өмчийн мэдээлэл 2004. №8 (147). х. 13

5. Александрова Г.П., Гришенко Г.Л., Фадеева Т.В., Медведева С.А., Сухов Б.Г., Трофимов Б.А Средство, обладающее антимикробной активностью Патент России № 2278669 С1 Опубл. 27.06.2006 Бюл. № 18

6. Казыцина. Л.А., Куплетская Н.Б. Применение УФ-, ИК-, ЯМР- и массспектроскопии в органической химии.- М.: МГУ.- 1979.- 238 с.

7. Помогайло А.Д., Розенберг А.С., Уфлянд И.Е. Наночастицы металлов в полимерах. - М.: Химия, 2000. - 672 с.

8. Ершов Б.Г. Наночастицы металлов в водных растворах: электронные, оптические и каталитические свойства// Российский химический журнал. - 2001. - T.XLV. - №3. - C.20-30.

9. Сергеев Г.Б. Нанохимия. - М.: Изд-во МГУ, 2003.- 288c. 


\begin{abstract}
The new suitable method, which is based on aggregation on the surface that has a special ability to absorb by the inorganic centre from a water solution, of multifunctional biogenic polymer, is used to synthesize organic-inorganic hybrid nano-composite. We extracted the humus substances or biogenic stabilizers from natural raw materials - peloid. And the stabilizers used for synthesize nano-composite after making complete allocation and specification of structures on it. The stabilizers' special ability to absorb by the inorganic centre can make the condition for self-producing of organic-inorganic hybrid nano-composite. As a result measurement on devices micro analyze of elements, AAS, IR-, UV- spectrometer, X-RAY it has been established properties received nano-composite.

We had worked out a method, which for synthesis organic and inorganic hybrid nano-composite by using the new nano stabilizer. We find possibility to solve some problems by using humus substances as the organic stabilizer of a new kind for nano-composites. Humus substances have the diversified molecular structure, which could spent through it one or several nano-composites, which have size corresponding primary globules. It gives the chance to stabilize a water solution and nano-composites, also to control biologically-activity of nano-composites by changing ratio of humus substances and nano-composites. Because of the humus substances are widespread and inexpensive raw materials of a natural origin, it is very good idea, that using the substances for creating brand new silver contained nano-composite materials.
\end{abstract}

